\title{
Mixed Blessings from a Cambridge Union, Elizabeth N Anionwu
}

\author{
2016. London: ELIZAN. ISBN 978-0-9955268-0-8
}

\author{
Peter S. Harper ${ }^{1}$
}

Received: 17 October 2018 / Accepted: 17 October 2018 / Published online: 27 October 2018

๑) Springer-Verlag GmbH Germany, part of Springer Nature 2018

How little we usually know about the people responsible for the medical and scientific work that we read about or are involved with personally! Perhaps, eventually, we may come across an obituary; if a person is really famous, then there may be a biography, or some of us may write our memoirs, mainly unpublished, for our family or just for ourselves. But for most 'ordinary' workers who have nevertheless given a lifetime of work to their field, we know next to nothing about themselves as people.

Many seem to prefer it this way; in a series of interviews with workers in human genetics that I made, I found that a surprising number were reluctant to believe that their life could be of any interest to others. Yet they are wrong, even if their lives appear to have been uneventful, as witnessed by the widespread interest shown in their stories when the transcripts of the series were placed on the internet; the clerical staff doing the transcribing, knowing nothing about genetics, equally found themselves fascinated by the stories of the interviewees.

So it is a rare privilege to read the story of the life and work of one such worker, Elizabeth Anionwu, especially when it involves not only pioneering contributions to an important genetic disorder, sickle cell disease, but also tells frankly of the difficulties needing to be overcome before these contributions could be made.

Elizabeth Anionwu will be known, personally or by name, to many British medical geneticists and genetic counsellors, especially those involved with the haemoglobinopathies, but those working elsewhere in Europe may be less familiar with her. All of us can be grateful for such an honest, if at times painful account of her life and work, which cannot have been easy to write or to make public.

Peter S. Harper

HarperPS@cardiff.ac.uk

1 Cardiff University, Cardiff, UK
Elizabeth's early life was a far from easy one; born to a highly intelligent mother from a poor family of Irish background and an equally bright Nigerian father, both students at Cambridge University, the combined stigma at the time (the 1940s) of being both mixed race and illegitimate led to her being brought up partly in care and partly in extreme poverty by her mother, who had sadly been forced by events to abandon hopes for her own career and had married an abusive man. Setting her heart on a nursing career after this unsettled childhood, Elizabeth was eventually able to enter nurse training, as well as to establish contact with her father, leading to her linking with the London black community and becoming an activist for promoting improved health and other services as a community nurse.

This in turn led to her involvement with initiating genetic and other services for sickle cell disease patients and families, first through haematology and then as university lecturer based at the clinical genetics unit of the Institute of Child Health, London, with Marcus Pembrey. More than any other person she has been responsible for ensuring that these services have become a recognised and established part of NHS services across Britain, though only after long and persistent campaigning for them in the face of widespread indifference and at times prejudice.

Returning to her community nursing roots during the later part of her career, she became Professor of Community Nursing at University of West London and was able to see her earlier sickle cell work widely accepted and respected.

Elizabeth Anionwu writes about her life and work, even the traumatic parts, vividly and with a strong sense of humour. Her determination, in both her professional and personal life, shows strongly throughout the whole book, making one realise how fortunate we are to have had such people in or associated with the field of medical geneticsand to wish that more would put their experiences on record so honestly and graphically as she has done. 